\title{
EKSISTENSI PANCASILA SEBAGAI SUMBER SEGALA SUMBER HUKUM DALAM KONSTITUSI INDONESIA
}

\author{
Sholikul Hadi \\ Fakultas Syariah Universitas Islam Negeri (UIN) KH Achmad Siddi Jember \\ Jl. Mataram No. 1 Mangli, Jember 68136, Jawa Timur, Indonesia| \\ Hadi76stain@gmail.com \\ DOI: https://doi.org/10.35719/ijl.v3i2.128
}

Abstract: The formulation of Pancasila in the Preamble to the 1945 Constitution of the Republic of Indonesia has a position as a staatsfondamentalnorm, so that Pancasila is the source of all sources of law and the highest legal order in Indonesia. The affirmation of Pancasila as the source of all sources of law in laws and regulations has been carried out since the New Order era until now through MPRS/MPR Decrees and laws. However, the function of Pancasila as the source of all sources of law is not fully applicable both in the New Order era which favors Pancasila more and in the reform era with many laws and regulations being canceled because they are contrary to higher provisions. The regulation of Pancasila as the source of all sources of law is not in the Constitution as the highest source of law but in the law itself has an impact on conflicting norms. This paper intends to conduct a critical analysis of the existence of Pancasila in the constitution where it is necessary to include the terms "Pancasila" and "Pancasila as the source of all sources of law" in the constitution in Indonesia so that Pancasila is truly used as the basis of the state

Keywords: Pancasila, the source of all sources of law, the Constitution.

Abstrak: Rumusan Pancasila dalam Pembukaan UUD NRI 1945 memiliki kedudukan sebagai staatsfondamentalnorm, sehingga Pancasila merupakan sumber dari segala sumber hukum dan

\section{IJLIL: INDONESIAN JOURNAL OF LAW AND ISLAMIC LAW VOLUME 3 NOMOR 2 JULI-JDESEMBER 2021; ISSN 2721-5261 E-SSN 2775-460X}


tertib hukum tertinggi di negara Indonesia. Penegasan Pancasila sebagai sumber dari segala sumber hukum dalam peraturan perundang-undangan dilakukan sejak era orde baru hingga saat ini melalui Ketetapan MPRS/MPR dan undang-undang. Namun demikian fungsi Pancasila sebagai sumber dari segala sumber hukum tidak sepenuhnya berlaku baik di era orde baru yang lebih mengkultuskan Pancasila maupun di era reformasi dengan banyaknya produk hukum yang dibatalkan karena bertentangan dengan peraturan yang lebih tinggi. Pengaturan Pancasila sebagai sumber dari segala sumber hukum tidak dalam UndangUndang Dasar sebagai sumber hukum tertinggi melainkan dalam undang-undang itu sendiri berdampak pada konflik norma. Tulisan ini bermaksud melakukan analisis kritis tentang keberadan Pancasila dalam konstitusi dimana perlunya pencantuman istilah "Pancasila" dan "Pancasila sebagai sumber segala sumber hukum" dalam konstitusi di Indonesia agar Pancasila sungguh-sungguh dijadikan sebagai dasar negara.

Keywords: Pancasila, sumber dari segala sumber hukum, Konstitusi.

\section{Pendahuluan}

Sehari setelah bangsa Indonesia memproklamasikan kemerdekaannya yakni tanggal 18 Agustus 1945, PPKI (Panitia Persiapan Kemerdekaan Indonesia) yang diketuai oleh Ir. Soekarno mengesahkan dan menetapkan Undang-Undang Dasar Negara Kesatuan Republik Indonesia yang kemudian dikenal dengan sebutan Undang-Undang Dasar 1945.' Pengesahahan Undang-Undang Dasar 1945 adalah sebagai konsekuensi

'Dalam naskah Pembukaan ditulis dengan redaksi Undang-Undang Dasar Negara Republik Indonesia Tahun 1945 
yuridis atas peristiwa Proklamasi Kemerdekaan RI tanggal 17 Agustus 1945 dimana sejak bangsa Indonesia merdeka maka hukum yang berlaku adalah hukum nasional dan sekaligus untuk dijadikan pedoman dalam penyelenggaraan tatanan bernegara.

Dengan adanya pengesahan Undang-Undang Dasar 1945 ini berarti bahwa sejak tanggal 18 Agustus 1945 bangsa Indonesia sudah memiliki konstitusi yang sah. Sri Sumantri M. berpandangan bahwa konstitusi sama dengan Undang - Undang Dasar. Penyamaan makna dari dua hal tersebut dalam praktiknya digunakan oleh banyak negara termasuk Indonesia dalam sistem ketatanegaraan. $^{2}$

Undang-Undang Dasar 1945 meliputi 2 (dua) bagian yakni Pembukaan dan batang tubuh. Bagian Pembukaan berisikan pokok-pokok pikiran yang terbagi atas 4 (empat) alinea, sedangkan bagian batang tubuh terdiri atas 16 Bab yang di dalamnya ada 37 Pasal, Pasal Aturan Peralihan dan yang terakhir 2 ayat Aturan Tambahan. Di

${ }^{2}$ Dahlan Thaib, dkk, Teori dan Hukum Konstitusi, (Jakarta: PT Raja Grafindo Persada, 2008), 8. Penganut paham modern yang tegastegas memberikan pengertian sama antara konstitusi dengan Undang-Undang Dasar adalah C.F. Strong dan James Bryce. Sedangkan ahli hukum yang memberikan pengertian beda antara konstitusi dengan Undang-Undang Dasar adalah Herman Heller dan F. Lassale. Lihat lebih lanjut dalam Dahlan Thaib, dkk, Teori dan .Hukum Konstitusi, PT RajaGrafindo Persada, Jakarta, 2008, hal. 9-14. 
dalam alinea keempat ada beberapa kalimat “.... dengan berdasarkan kepada Ketuhanan Yang Maha Esa, Kemanusiaan yang adil dan beradab, Persatuan Indonesia dan Kerakyatan yang dipimpin oleh hikmat kebijaksanaan dalam permusyawaratan / perwakilan, serta dengan mewujudkan suatu Keadilan sosial bagi seluruh rakyat Indonesia.”. Rumusan kalimat tersebut oleh para pendiri bangsa yang tergabung dalam PPKI dinyatakan sebagai Pancasila yang dipergunakan sebagai dasar Negara Indonesia.

Rumusan dasar negara ini merupakan penyempurnaan atas rumusan dasar negara hasil Panitia 9 yang diterima bulat oleh Badan Pernyelidik Usaha Persiapan Kemerdekaan Indonesia (BPUPKI), yaitu sepanjang mengenai Sila pertama yang semula berbunyi: Ketuhanan, dengan kewajiban menjalankan syariat Islam bagi pemeluk-pemeluknya menjadi Ketuhanan Yang Maha Esa, dan sila keempat dengan mengganti tanda penghubung (-) menjadi tanda garis miring (/) di antara kalimat permusyawaratan dan perwakilan. Dengan langkah pengesahan pada UUD Negara Kesatuan RI oleh PPKI, maka mulai saat itulah Pancasila sebagai dasar negara RI telah berlaku secara sah dan menjadi rumusan final, karena telah disahkan oleh 
suatu Badan Nasional yang memiliki fungsi membentuk dan mendirikan Negara RI yang mana menurut Hukum Tata Negara memiliki wewenang menetapkan Pokok Kaidah Negara yang fundamental (staatsfundamentalnorm). ${ }^{3}$

Rumusan Pancasila dalam Undang-Undang Dasar 1945 ini sesuai dengan teori hukum konstitusi yang dikemukakan oleh KC Wheare dan Podsnap. Menurut KC Wheare, ${ }^{4}$ materi muatan konstitusi minimal mencakup:

a. Susunan sistem pemerintahan (structure of government), yakni tentang lembaga eksekutif, lembaga yudikatif, dan lembaga legislatif;

b. Hubungan atau relasi timbal balik antara lembaga negara yang satu dengan yang lain;

c. Hubungan antara lembaga-lembaga negara dengan masyarakat (community) atau warga negara (citizen);

d. Pernyataan atas perlindungan terhadap hak-hak warga negara (declaration of the guarantee of the right of the subject); dan

3 Subandi Al Marsudi, Pancasila dan UUD '45 dalam Paradigma Reformasi, (Jakarta: PT Raja Grafindo Persada , 2006), 32.

${ }^{4}$ I Dewa Gede Atmadja, Hukum Konstitusi: Problematika Konstitusi Indonesia Sesudah Perubahan Undang-Undang Dasar 1945, (Malang: Setara Press, 2012), 70. 
e. Tujuan atau cita-cita politik bangsa atau negara. Citacita politik ini menjadi tujuan dan sumber penyelenggaran pemerintahan yang mengikat dari aspek hukum (legally binding) badan eksekutif, badan yudikatif, dan badan legislatif.

Sedangan menurut Podsnap, ${ }^{5}$ materi atau isi konstitusi akan merupakan:

a. a sort manifesto (ketentuan tentang pernyataan kebijakan);

b. a confession of faith (pernyataan mengenai kepercayaan);

c. a statement of ideals (pernyataan tentang cita-cita negara);

d. a charter of the land (suatu piagam negara).

Memenuhi muatan materi konstitusi yang dimaksud adalah mengenai cita-cita atau tujuan politik bangsa atau negara sebagaimana yang dikemukakan oleh KC Wheare dan merupakan a statement of ideals (pernyataan tentang cita-cita negara) sebagaimana pendapat Podsnap.

Menurut Cholisin, ${ }^{6}$ Pembukaan Undang-Undang Dasar 1945 menunjukkan bahwa Pancasila adalah dasar

${ }^{5}$ Ibid, 70-71 
negara, sehinggga Pancasila merupakan nilai dasar normatif terhadap semua penyelengaraan pemerintahan negara Republik Indonesia. Dengan istilah lain bahwa Pancasila merupakan Ideologi Negara atau Dasar Falsafah Negara, karena di dalamnya mengandung nilai yang paling mendasar untuk menentukan dan menjadi standar keabsahan semua model pengelolaan negara serta putusan-putusan strategis dalam penyelenggaraan pemerintahan. Pancasila sebagai ideologi negara berarti pula bahwa Pancasila merupakan doktrin, teori, ajaran, dan/atau teori tentang cita-cita (idea) yang ditata secara tersistem sampai dengan petunjuk pelaksanaannya yang jelas, dan diyakini kebenarannya oleh bangsa Indonesia.

Di dalam hubungannya dengan tertib hukum nasional, kedudukan Pembukaan Undang-Undang Dasar 1945 mempunyai dua hal yang sangat fundamental atau mendasar yaitu: pertama, menjadikan faktor-faktor mutlak bagi adanya tertib hukum negara Indonesia, dan kedua, menjadi bagian integral dalam tertib hukum negara Indonesia sebagai tertib hukum

${ }^{6}$ Cholisin, Pancasila Sebagai Ideologi Negara dan Relevansinya dengan Kondisi Saat ini, http://staffnew.uny.ac.id/upload/131474282/ pengabdian/mgmppkn-wates-28-sep-2011-ideologi-negara-dan-relevansinya-dengankondisi-saat-ini.pdf, diakses tanggal 26 April 2020. 
yang tertinggi. ${ }^{7}$ Kedudukan yang seperti ini dalam tertib hukum negara Indonesia, maka Pembukaan UndangUndang Dasar 1945 menentukan adanya tertib hukum Indonesia. Akibatnya adalah bahwa Pembukaan Undang-Undang Dasar 1945 pada aspek hukum keberadaannya tidak dapat diubah.

Begitu pula rumusan Pancasila yang dituangkan dalam Pembukaan Undang-Undang Dasar 1945 adalah merupakan pemberian bentuk hukum terhadap kesempatan politis bangsa Indonesia di dalam bernegara. Sejarah kenegaraan menunjukkan bahwa apapun konstelasi politik yang dibentuk berdasarkan struktur formal yang ada, tidak berhasil menghilangkan Pancasila sebagai pemersatu bangsa. Di dalam sejarah kenegaraanpun nampak bahwa segala macam cara diusahakan untuk menjamin eksistensi dan kelestarian Pancasila dari masa ke masa seperti dalam tahun 1945, masa negara Indonesia Serikat, masa negara Kesatuan berdasarkan Undang- Undang Dasar Sementara 1950, masa Orde Lama dengan Undang-Undang Dasar 1945, sampai pada masa orde baru, masing-masing dengan

\footnotetext{
${ }^{7}$ Kaelan., Pendidikan Pancasila, (Yogyakarta: Paradigma, 2010), 148.
} 
berbagai bentuk dan cara pengamanannya. ${ }^{8}$ Paska orde baru yakni era reformasi juga demikian halnya. Negara yang telah melakukan amandemen atau perubahan Undang-Undang Dasar 1945 sampai dengan empat kali tetap mempertahankan (tidak mengubah) Pembukaan Undang-Undang Dasar 1945 yang mana di dalamnya ada rumusan Pancasila.

Menurut Kaelan, ${ }^{9}$ Pembukan Undang-Undang Dasar 1945 terbagi dalam empat alinea, dan di setiap alinea mempunyai spesifikasi atau ciri khas apabila ditelaah berdasarkan isinya. Alenia pertama, alenia kedua dan alenia ketiga memuat suatu pernyataan yang tidak berhubungan secara kausal organis dengan batang tubuh atau pasal-pasalnya. Pada bagian ini memuat beberapa pernyataan yang menerangkan serangkaian peristiwa sebelum terciptanya negara Indonesia. Adapun bagian keempat (Alenia ke-4) menjelaskan dasar-dasar fundamental negara yakni tujuan negara Indonesia, ketentuan UUD negara, bentuk negara dan philosofischegrondslag (dasar filsafat negara) Pancasila. Oleh karena itu Alenia IV mempunyai hubungan "kausal

${ }^{8}$ Padmo Wahyono, Beberapa Masalah Ketatanegaraan di Indonesia, (Jakarta: Rajawali, 1994), 21-22.

${ }^{9}$ Kaelan, op cit, 148 
organis' dengan pasal-pasal UUD 1945, sehingga sangat erat kaitannya dengan materi pasal-pasal tersebut.

Dengan demikian rumusan Pancasila yang terdapat di dalam Pembukaan Undang-Undang Dasar 1945 merupakan sumber dari segala sumber hukum Indonesia, termasuk dalam masalah ini dijadikan sebagai pedoman penyusunan naskah pasal-pasal atau batang tubuh Undang-Undang Dasar 1945. Negara Indonseia merupakan negara hukum (rechtstaat). ${ }^{10}$ Sebagai negara hukum, maka Pancasila yang berfungsi sebagai sumber dari segala sumber hukum memiliki kedudukan dan fungsi yang sangat penting dalam penyelenggaraan negara.

Menurut sejarah berlakunya konstitusi di Indonesia, rumusan Pancasila telah dimuat dalam konstitusi pada bagian Pembukaan (mukaddimah) meskipun dengan redaksi yang berbeda-beda akan tetapi pada prinsipnya memiliki makna yang hampir sama. Dengan dimuatnya rumusan Pancasila dalam pembukaan, Pancasila memiliki kedudukan sebagai Pokok Kaidah Negara yang fundamental (staatsfundamentalnorm) sehingga menjadi tertib hukum tertinggi dan menjadi sumber dari segala sumber hukum di Indonesia. Akan tetapi

\footnotetext{
${ }^{10}$ Pasal 1 ayat (3) .Undang-Undang Dasar 1945.
} 
masalahnya adalah istilah "Pancasila" dan "Pancasila sebagai sumber dari segala sumber hukum" tidak ditemukan atau tidak diatur dalam konstitusi di Indonesia.

\section{Pembahasan}

Eksistensi Pancasila sebagai sumber segala sumber hukum di Indonesia

Pancasila sebagai staatsfundamentalnorm (sumber segala sumber hukum) pertama kali dikemukakan oleh Prof. Notonagoro." ${ }^{11}$ Sebagai staatsfundamentalnorm dalam ketatanegaraaan RI, maka Pancasila semestinya dijadikan kaidah pokok dalam pembuatan dan pelaksanaan hukum di Indonesia. Sebagai sumber dari segala sumber hukum, Pancasila memiliki 4 (empat) kaidah penuntun hukum yang harus dijadikan pedoman dalam politik hukum dan pembentukan perundangundangan pada umumnya, yaitu: $:^{12}$

1. Melindungi tanah air dan bangsa Indonesia yang berarti semua hukum yang dibuat dan

"Kurnisar, Pancasila Sumber dari Segala Sumber Hukum di Indonesia, Jurnal Undhiksa ISSN 1412 - 8683 Volume 10, Nomor 2 Tahun 2011, 246

${ }_{12}$ Moh. Mahfud MD, Ideologi, Konstitusi dan Tata Hukum Kita, dalam Prosiding Revitalisasi Ideologi Pancasila dalam Aras Global Perspektif Negara Hukum, Fakultas Hukum Unnes, 16 November 2016, 33-34 
diberlakukan harus mampu menjaga keutuhan kesatuan bangsa baik secara teritori (wilayah) maupun ideologi.

2. Membangun kedaulatan hukum (nomokrasi) dan kedaulatan rakyat (demokrasi) secara terpadu yang berarti hukum harus dapat membatasi pelaksanaan demokrasi dan hukum harus dibentuk secara demokratis. Keputusan dengan cara demokratis yang melanggar konstitusi dapat dianulir oleh lembaga nomokratis seperti Mahkamah Konstitusi atau Mahkamah Agung, sesuai levelnya.

3. Mewujudkan keadilan sosial bagi seluruh rakyat Indonesia yang berarti hukum yang berlaku harus menutup peluang tumbuhnya sistem eksploitasi oleh yang kuat terhadap yang lemah dan harus selalu berupaya untuk mengurangi kesenjangan dalam masyarakat,

4. Membangun toleransi kehidupan beragama yang berkemanusiaan yang berarti hukum di Indonesia tidak boleh membeda-bedakan pemeluk agama berdasarkan apapun. Negara juga tidak menjadikan agama tertentu sebagai sumber hukum, akan tetapi negara harus melindungi 
semua pemeluk agama dalam menjalankan agamanya.

Ketentuan mengenai Pancasila sebagai sumber segala sumber hukum dapat ditemukan dalam perundang-undangan baik di era orde baru maupun era reformasi. Di era orde baru, Pancasila sebagai sumber dari segala sumber hukum telah diatur dalam Tap MPR Nomor XX/MPRS/1966 jo Tap MPR Nomor V/MPR/1973 jo Tap MPR Nomor IX/MPR/1978. Adapun di era reformasi diatur dalam Tap MPR Nomor III/MPR/200o, UU Nomor 10 Tahun 2004 tentang Pembentukan Peraturan Perundangundangan $\left(\mathrm{P}_{3}\right)$ dan UU Nomor 12 Tahun 2011 tentang $\mathrm{P}_{3}$ sebagai pengganti UU 12/2014.

Hal pokok yang diatur dalam Tap MPR Nomor XX/MPRS/1966 jo Tap MPR Nomor V/MPR/1973 jo Tap MPR Nomor IX/MPR/1978 adalah bahwa Pancasila sebagai sumber dari segala sumber hukum beserta penegasan penyempurnaannya. Pancasila sebagai sumber dari segala sumber hukum adalah kesadaran, cita-cita moral dan pandangan hidup (way of life) yang meliputi suasana watak dan kejiwaan rakyat negara yang bersangkutan. Pengertian ini menunjukkan bahwa Pancasila merupakan sumber, dasar, ruh/spirit, karakter dan cita hukum Indonesia. 
Lalu, bagaimana implementasi kedudukan Pancasila dalam hukum tersebut di era orde baru?

Sebagai antitesa dari pelanggaran Pancasila sebagai faktor utama penyebab kegagalan dan tumbangnya rezim orde lama, di awal kekuasaannya orde baru telah mencanangkan pelaksaaan Pancasila dan UUD 1945 secara murni dan konsekuen. Prioritas utamanya pembangunan ekonomi dan mengedepankan stabilitas nasional. Pancasila disakralkan dan dikultuskan sehingga menjadi ideologi tertutup dengan penafsiran tunggal milik pemerintah. Mereka yang mendukung penuh pemerintah dikategorikan sebagai Pancasialis, sementara pihak-pihak yang berseberangan bahkan hanya memberikan kritik atas kebijakan atau policy pemerintah distempel anti Pancasila.

Dengan adanya pengkultusan dan menjadikan Pancasila "sakral" maka setiap aspek kehidupan dalam berbangsa, bernegara dan bermasyarakat baik secara politik, ekonomi, sosial dan hukum wajib melaksanakan Pancasila sesuai versi/kehendak rezim. Hal ini berarti segala aspek kehidupan tidak boleh menyimpang dengan Pancasila. Namun demikian, dalam pelaksanaan Pancasila secara murni dan 
konsekuen tersebut, rezim orde baru menerapkan kekuasaan otoritarian yang mengabaikan Hak Asasi Manusia (HAM) dan membelenggu kebebasan rakyat. Misalnya, penanganan gerakan sparatis dengan pendekatan militeristik semata, membredel media massa yang kritis terhadap pemerintah, menghabisi aktivis HAM, dan sebagainya. Realitas semacam ini menyebabkan gejolak dan ketidakpuasan rakyat kepada orde baru bahkan juga terhadap Pancasila yang dipaksa menjadi ideologi tertutup dan sekaligus Pancasila yang identik dengan orde baru, sehingga kegagalan orde baru sama dengan kegagalan Pancasila. Ketidakpuasan rakyat Indonesia mencapai puncaknya dengan pengunduran diri Suharto sebagai Presiden RI kedua tanggal 21 Mei 1998. Peristiwa yang dijadikan sebagai awal masa reformasi tersebut juga dilatarbelakangi tidak puasnya rakyat pada krisis multi dimensi baik dalam bidang politik, ekonomi, hukum maupun kebebasan. ${ }^{13}$ Dari uraian tersebut dapat dikatakan bahwa rezim orde baru belum benarbenar menjadikan Pancasila sebagai sumber segala sumber hukum dan Pancasasila justru dijadikan

${ }_{13}$ Fais Yonas Bo'a, Pancasila sebagai Sumber Hukum dalam Sistem Hukum Nasional, Jurnal Konstitusi, Volume 15, Nomor 1, Maret 2018 36-37 
sebagai alat kekuasaan untuk memukul lawan politik dan melanggengkan kekuasaan.

Di era reformasi sebagaimana dijelaskan di atas, Pancasiala sebagai sumber dari segala sumber hukum dimuat dalam Tap MPR Nomor III/MPR/20oo, UU No. 10 Tahun 2004 dan UU No. 12 Tahun 2011 sebagai pengganti UU 10/2014. Pasal 1 Tap MPR Nomor III/MPR/20oo tentang Sumber Hukum dan Tata Urutan Peraturan Perundang-undangan mengatur dalam ayat (3) yang pada intinya bahwa Pancasila sebagaimana dimuat dalam Pembukaan UUD 1945 sebagai sumber norma dasar (grundnorm) yang ini bermakna Pancasila merupakan staatfondamental norm (pokok kaidah negara yang fondamental) dan berarti pula Pancasila sebagai sumber dari segala sumber hukum.

UU Nomor 10 Tahun 2004 tentang Pembentukan Peraturan Perundang-undangan memuat ketentuan yang berbunyi "Pancasila merupakan sumber dari segala sumber hukum negara"14 dan diperjelas dalam Penjelasan bahwa "Penempatan Pancasila sebagai sumber dari segala sumber hukum negara adalah sesuai dengan Pembukaan UUD Negara Republik

\footnotetext{
${ }^{14}$ Pasal 2 UU Nomor 10 Tahun 2004
} 
Indonesia Tahun 1945 yang menempatkan Pancasila sebagai dasar dan ideologi negara serta sekaligus dasar filosofis bangsa dan negara sehingga setiap Materi Muatan Peraturan Perundang-undangan tidak boleh bertentangan dengan nilai-nilai yang terkandung dalam Pancasila". ${ }^{15}$ Pasal 2 ini mempertegas ketentuan Pasal 1 ayat (3) TAP MPR No. III/MPR/20oo sekaligus menekankan bahwa materi muatan UUD 1945, undang-undang, perppu, peraturan pemerintah, peraturan presiden, peraturan daerah dan seluruh Peraturan Perundang-undangan lainnya harus sesuai dan tidak boleh bertentangan dengan Pancasila. ${ }^{16}$ Sedangkan UU Nomor 12 Tahun 2011 menyebutkan dalam Pasal 2 bahwa "Pancasila merupakan sumber segala sumber hukum negara” dan dijabarkan dalam Penjelasan "Penempatan Pancasila sebagai sumber dari segala sumber hukum

\footnotetext{
15 Penjelasan Pasal 2 UU Nomor 10 Tahun 2004

16 Kesesuaian Pancasila dengan peraturan perundang-undangan sesuai dengan kriteria konsistensi sebagaimana dikemukakan Kuntowijoyo dalam artikelnya berjudul "Radikalilasasi Pancasila". Sila dalam Pancasila harus memiliki hubungan terpadu, teks dengan teks, dengan dokumen-dokumen lain seperti UUD beserta penjelasannya, Keputusan MPR, Keputusan Presiden, Peraturan Pemerintah, dan pernyataan pejabat. https://www.eramuslim.com/berita/analisa/dr-kuntowijoyoradikalisasi-pancasila.htm/2\#.YYe_VıVBzIU, diakses tanggal 5 November 2021.
} 
negara adalah sesuai dengan Pembukaan UUD NRI Tahun 1945 alinea keempat yaitu Ketuhanan Yang Maha Esa, Kemanusiaan yang adil dan beradab, Persatuan Indonesia, Kerakyatan yang dipimpin oleh hikmat kebijaksanaan dalam Permusyawaratan/ Perwakilan, dan Keadilan sosial bagi seluruh rakyat Indonesia”. Ketentuan ini sama dengan UU 10/2004, akan tetapi berbeda dalam penjelasannya, dimana UU 10/2014 lebih tegas dengan mengamanatkan agar semua jenis peraturan perundang-undangan harus sesuai dengan Pancasila. Dengan demikian dapat dikatakan terjadinya kemunduran mengenai pengaturan Pancasila sebagai sumber segala sumber hukum dalam Pasal 2 UU 12/2011.

Lalu, bagaimana implementasi Pancasila sebagai sumber dari segala sumber hukum di era reformasi sampai dengan saat ini? Era reformasi merupakan momen beralihnya kekuasaan otitarian menjadi demokratis dan berkeadilan. Namun demikian, menurut Fais Yonas Bo'a ${ }^{17}$ bukan berarti reformasi tanpa mempunyai kerugian. Salah satu kerugian di era reformasi adalah terkikisnya Pancasila sebagai sumber segala sumber hukum dalam sistem hukum

${ }^{17}$ Ibid, 38 
nasional. Paling tidak ada tiga alasan terkikisnya Pancasila sebagai sumber segala sumber hukum sejak reformasi sampai dengan saat ini, yakni adanya: (1) sikap resistensi atas orde baru, (2) menguatnya pluralisme hukum, dan (3) kenyataan hukum yang menempatkan Pancasila sebagai lambang/simbol semata.

Mengenai alasan ketiga, Fais Yonas Bo'a menjelaskan bahwa hal yang paling nyata untuk menggambarkan formalitas Pancasila dalam materi muatan perundang-undangan adalah begitu banyaknya gugatan-gugatan hukum melalui langkah pengujian undang-undang (judicial review) terhadap UUD 1945 di Mahkamah Konstitusi. ${ }^{18}$ Menurut data pada laman resmi Mahkamah Konstitusi, ${ }^{19}$ rekapitulasi putusan pengujian UU sampai dengan tanggal 5 November 2021 sebanyak 1451 (44\% dari perkara yang diajukan ke MK). Dari jumlah tersebut, putusan yang dikabulkan 105 perkara, dikabulkan sebagian 174 perkara, putusan ditolak 524 perkara, putusan tidak dapat diterima 468 perkara, putusan tidak berwenang 12 perkara, gugur 23 perkara, dan ditarik kembali 145 perkara. Berdasarkan data

${ }^{19}$ https://www.mkri.id/index.php?page=web.Perkara2\&menu=4 
tersebut, sejak awal dibentuknya Mahkamah Konstitusi tahun 2003 sampai saat ini sebanyak 279 perkara amar putusannya adalah dikabulkan. Hal ini menunjukkan bahwa 279 materi muatan dalam UU yang bertentangan dengan UUD 1945 dan sekaligus adanya ketidaksungguhan pembentuk UU merujuk UUD 1945 dalam pembentukan UU.

Demikian pula dengan pembentukan perundangundangan berupa peraturan daerah. Di tahun 2016 Kementerian Dalam Negeri mempublikasikan 3.143 peraturan daerah yang dibatalkan/direvisi oleh pemerintah pusat, dengan rincian 1.765 Perda atau Perkada kabupaten/kota yang dicabut/direvisi Mendagri, 111 peraturan/putusan Mendagri, dan 1.267 Perda/perkada kabupaten/kota yang dicabut atau direvisi gubernur. Presiden Jokowi mengatakan perda yang dibatalkan itu adalah perda yang menghambat proses perizinan dan investasi serta menghambat kemudahan berusaha, dan perda yang bertentangan dengan praturan perundang-unangan yang lebih tinggi (sehingga berlaku asas lex superiori derogat legi inferiori, pen). ${ }^{20}$

20 https://beritagar.id/artikel-amp/berita/daftar-perda-bermasalahyang-dibatalkan-pemerintah, diakses tanggal 5 November 2021 


\section{Memposisikan Pancasila sebagai sumber segala} sumber hukum dalam konstitusi di Indonesia

Sebagaimana diuraikan sebelumnya, Pancasila memiliki fungsi dan kedudukan sangat penting dalam ketatanegaraan terutama sebagai sumber dari segala sumber hukum, akan tetapi realitasnya kriteria “konsistensi” implementasi nilai-nilai Pancasila dalam wujud adanya kesesuain anatara Pancasila dengan peraturan perundang-undangan belum benar-benar dilaksanakan. Dengan demikian maka Pancasila seharusnya diposisikan secara tepat dalam struktur tata hukum di Indonesia dan sekaligus perlunya mempertegas kedudukan Pancasila sebagai sumber dari segala sumber hukum.

Menurut Hans Nawiasky dengan teorinya yang disebut theori von stufenufbau der rechtsordnung, susunan norma adalah: ${ }^{21}$

1. Staatsfondamentalnorm (Norma fundamental negara)

2. staatgrundgesetz (Aturan dasar negara)

3. formell gesetz (Undang-undang formal)

4. verornung en autonome satzung (peraturan pelaksanaan)

${ }^{21}$ Jimly Asshiddiqie dan M. Ali Safa'at, Teori Hans Kelsen tentang Hukum, (Jakarta: Setjen dan Kepaniteraan MK-RI, 2006), 170 
Berpijak pada teori tersebut, Attamimi berpendapat bahwa struktur tata hukum Indonesia adalah:22

1. Staatsfondamentalnorm, yaitu: Pancasila (Pembukaan UUD 1945)

2. Staatgrundgesetz, yaitu: batang tubuh UUD 1945, Tap MPR, dan Konvensi Ketatanegaraan

3. formell gesetz, yaitu: undang-undang

4. verornung en autonome satzung, yaitu: secara hirarkis mulai dari Peraturan Pemerintah hingga Keputusan Bupati atau Walikota

Berdasarkan pendapat Attamimi tersebut Pancasila yang tercantum dalam Pembukaan UUD NRI 1945 merupakan staatsfondamentalnorm sehingga menempati urutan tertinggi dalam struktur tata hukum Indonesia. Sehingga Fais Yonas Bo'a $^{23}$ memandang perlunya mendudukan Pancasila sebagai puncak hirarki peraturan perundang-undangan. Dengan demikian tata urutan peraturan perundang-undangan dari atas ke bawah menjadi sebagai berikut: Pancasila, Undang-Undang Dasar Negara Republik Indonesia Tahun 1945, Ketetapan Majelis Permusyawaratan Rakyat Republik Indonesia, Undang-

${ }^{22}$ Ibid, 171

${ }^{23}$ Op cit, 45 
Undang/Peraturan Pemerintah Pengganti UndangUndang, dan seterusnya.

Persoalannya adalah rumusan Pancasila yang dimuat dalam Pembukaan UUD NRI 1945 yang dengan sendirinya merupakan bagian dari UUD NRI 1945, sehingga dengan menempatkan Pancasila sebagai urutan tertinggi dalam hiraki peraturan perundang-undangan yang disusul di bawahnya UUD NRI 1945 akan menunjukkan seakan-akan Pancasila dan UUD NRI 1945 terpisah satu sama lain. Padahal antara Pembukaan (dimana di dalamnya terdapat rumusan Pancasila) dan batang tubuh merupakan satu kesatuan yang integral UUD NRI 1945 itu sendiri, meskipun Pembukaan memiliki derajat tertinggi karena memiliki hubungan langsung dengan spirit Proklamasi 17 Agustus 1945 dan di dalamnya terdapat rumusan dasar negara Pancasila.

Menjawab permasalahan di atas, penulis menilai perlunya memperkuat posisi Pancasila sebagai sumber dari segala sumber hukum dalam konstitusi di Indonesia dengan cara mencantumkan istilah "Pancasila" dan pengaturan Pancasila sebagai sumber dari segala sumber hukum dalam UUD NRI 1945.

Pancasila seharusnya diatur secara utuh dalam UUD 1945 sebagai konstitusi yang berlaku di Indonesia. Pengaturan tersebut tidak hanya secara 
esensial saja, akan tetapi juga secara formal yakni nama Pancasila itu sendiri. Meskipun hanya sebatas nama atau istilah, menurut hemat penulis "Pancasila" perlu dicantumkan dalam UUD 1945. Begitu juga dengan perlunya pengaturan fungsi "Pancasila sebagai sumber dari segala sumber hukum" dalam konstitusi. Berikut ini penulis uraikan beberapa alasan mengapa perlunya pencantuman kedua hal tersebut dalam UUD 1945.

Pertama, fakta sejarah menunjukkan bahwa istilah Pancasila muncul dalam persidangan pertama BPUPKI yang disampaikan oleh Soekarno tanggal 1 Juni $1945 \cdot{ }^{24}$ Prof. Mr. AG Pringgodigdo, dalam tulisannya berjudul Sekitar Pancasila, menulis "bahwa setelah pada tanggal 1 Juni 1945 diterima oleh semua

${ }^{24}$ Dalam pandangan Soekarno rumusan dasar negara meliputi: (1) Kebangsaan Indonesia, (2)Internasionalisme atau Perikemanusiaan, (3) Mufakat atau demokrasi, (4) Kesjahteraan social, dan (5) Ketuhanan yang berkebudayaan. Kelima prinsip itu disebut Soekarno dengan Panca Sila. "Sila artinya asas atau dasar, dan di atas kelima dasar itulah kita mendirikan bangsa Indonesia, kekal, dan abadi." Mengapa dasar meja statis dan Leitstar dinamis yang mempersatukan banga itu dibatasi lima? Jawaban Soekarno, selain kelima unsur itulah yang memang berakar kuat dalam jiwa bangsa Indonesia, dia juga mengaku suka pada simbolisme angka lima. Angka lima memiliki nilai "keramat" dalam antropologi masyarakat Indonesia. Soekarno menyebutkan, "Rukun Islam lima jumlahnya. Jari kita lima setangan... dan seterusnya (lihat Yudi Latif, Negara Paripurna Historisitas, Rasionalitas,, dan Aktualitas Pancasila, Gramedia Pustaka Utama, Jakarta, 2012, hal. 15-21. 
anggota Badan Penyelidik dengan tepuk tangan yang riuh kemudian setelah tanggal itu dalam tahun 1945 Pancasila tidak pernah disebut lagi, sehingga baik dalam Pembukaan maupun dalam Batang Tubuh UUD 1945 istilah itu tidak dijumpai." AG Pringgodigdo adalah wakil kepala sekretariat yang juga merangkap anggota BPUPK. Sehari-hari dia adalah wedana Purwokerto. Menurutnya, "Istilah Pancasila itu baru timbul kembali pada waktu Presiden Soekarno dalam bulan September 1947 mengeluarkan buku kecil yang memuat pidatonya dari 1 Juni 1945 di muka rapat Badan Penyelidik itu dengan judul: Lahirnya Pancasila. Sejak saat itulah Bung Karno mulai memperkenalkan Pancasila menurut perumusannya kepada masyarakat luas." Istilah Pancasila memang tak ditulis dalam Pembukaan UUD 1945 maupun di Batang Tubuh UUD 1945. Namun lima sila itu jelas tercantum di Pembukaan UUD 1945. Karena itu wajar jika orang tak pernah bercakap lagi soal Pancasila dan baru muncul kembali pada tahun 1947 sejak terbitnya buku Lahirnja Pantja Sila. ${ }^{25}$

\footnotetext{
${ }^{25}$ Nasihin Masha, Bermula dari Fragmentasi, Pengaburan Pancasila Yamin dan Desukarnoisasi Orba, REPUBLIKA.co.id Rabu 22 Jun 2016 12:01 WIB, diakses tanggal 6 Mei 2020.
} 
Berdasarkan pengalaman sejarah tersebut, istilah Pancasila telah disepakati oleh para Founding Father sebagai nama dasar negara, yang mana dasar negara tersebut dimuat dalam Pembukaaan Undang-Undang Dasar 1945. Pencantuman istilah Pancasila dalam naskah Undang-Undang Dasar 1945 sangat penting karena istilah tersebut merupakan hal yang mendasar untuk merumuskan peristiwa sejarah dalam konstitusi secara utuh (integral), sekaligus untuk memuat dasar negara dalam konstitusi tidak hanya secara esensial akan tetapi juga secara formal.

Kedua, Pancasila adalah "bahan baku" filosofis bagi penyusunan seluruh ketentuan peraturan perundang-undangan. Isi hukum harus merujuk kepada Pancasila sebagai basis nilainya, yang akan dituangkan dalam norma hukum. Pancasila sebagai sumber hukum materiil, setidaknya memiliki 3 (tiga) elemen sekaligus yakni volkgeist (jiwa bangsa), volkreich (jiwa rakyat), dan volkrecht (sumber dari segala sumber hukum). Bahwa suatu bangsa memiliki jiwa, dan jiwa suatu bangsa inilah yang menyebabkan masyarakat bangsa itu dapat hidup damai dan beradab. Jiwa bangsa terletak pada prinsip-prinsip dasar yang diikutinya. Dalam konteks bangsa 
Indonesia, jiwa bangsa (volkgeist) melekat pada Pancasila dan menjadi isi bagi standar normative -kode perilaku-- kolektif warga bangsa. Pancasila adalah merupakan bagian penting representasi dari jiwa rakyat (volkreich) Indonesia. Jiwa rakyat merupakan refleksi dinamis dari realitas perkembangan masyarakat Indonesia. Bangsa-bangsa sebagai subkultur masyarakat telah hidup berabadabad lamanya dan karenanya setiap perkembangannya bangsa-bangsa itu tidak sedinamis perkembangan "rakyat" sebagai pemilik bangsa. Persatuan dan kehendak rakyat yang kuat telah mengantarkan bangsa Indonesia menjadi bangsa merdeka, sehingga disebut juga sebagai negara Indonesia yang merdeka. Jiwa rakyat harus diresapi, dan Pancasila tetap menghendaki adanya tindakan dan keputusan negara Indonesia tetap memperhatikan apa yang terjadi dan timbul dalam masyarakat. Pancasila adalah sumber dari segala sumber hukum (volkrecht). Berdasarkan pendapat yang dikemukakan oleh Hans Kelsen mengenai teori hukum berjenjang, Pancasila merupakan philosophy grondslag, yakni filsafat dasar, bukan staatfundamentalnorm. Karena yang menjadi 
staatfundamentalnorm apabila dilihat secara seksama adalah Undang-Undang Dasar 1945 . $^{26}$

Ketiga, dalam peraturan perundang-undangan, istilah Pancasila justeru ditemukan dalam peraturan perundang-undangan di bawah Undang-Undang Dasar seperti Undang-Undang, Peraturan Pemerintah, Peraturan Presiden, dan Peraturan Daerah. Selain itu, istilah Pancasila dapat ditemukan juga dalam peraturan teknis seperti Peraturan Menteri, Peraturan lembaga/badan setingkat Menteri, dan sebagainya. Salah satu contoh adalah Undang-Undang yang mengatur tentang pedoman pembentukan peraturan perundang-undangan yakni UU Nomor 12 Tahun 2011 tentang Pembentukan Peraturan Perundang-Undangan. Pasal 2 UU tersebut mengatur bahwa Pancasila merupakan sumber segala sumber hukum negara. Ada dua hal yang menjadi perhatian dalam ketentuan pasal tersebut, yakni istilah Pancasila dan Pancasila merupakan sumber segala sumber hukum negara (Pancasila sebagai sumber dari segala sumber hukum). UUD 1945 sebagai konstitusi yang merupakan hukum yang

${ }^{26}$ Fajlurrahman Jurdi, Hukum Tata Negara Indonesia, (Jakarta: Prenadamedia Grup, 2019), 84-85. 
dianggap tinggi tingkatannya dan merupakan dasar pembuatan Undang-Undang tidak mengatur ketentuan tersebut. Dengan demikian dapat dikatakan bahwa ketentuan Pasal 2 UU No. 11 Tahun 2011 inkonsistensi dengan UUD 1945. Permasalahan tersebut tidak akan terjadi apabila dalam batang tubuh UUD 1945 sebagai grund gezetse (aturan dasar) memuat tentang istilah Pancasila dan fungsi Pancasila sebagai sumber dari segala sumber hukum.

Selain dengan pertimbangan tersebut, pengaturan Pancasila sebagai sumber dari segala sumber hukum dalam batang tubuh UUD NRI 1945 akan memperkuat fungsi Pancasila sebagai sumber hukum baik dalam pembentukan peraturan perundang-undangan khususnya undang-undang oleh DPR dan Presiden maupun dalam pengujian undang-undang terhadap UUD oleh Mahkamah Konstitusi. Selama ini Pasal "wajib" yang sering dijadikan pertimbangan dalam konsideran “menimbang” adalah Pasal 20 dan Pasal 21 UUD 1945 yang mengatur kewenangan DPR dalam membentuk UU. Dengan adanya tambahan Pasal yang memuat bahwa Pancasila sebagai sumber dari segala sumber hukum, maka pasal tersebut akan menjadi Pasal “wajib" yang harus ada juga dalam konsideran 
menimbang dalam suatu UU sehingga akan menjadi keharusan muatan materinya sesuai dengan Pancasila. Dalam pengujian UU terhadap UUD yang di dalamnya memuat pasal "Pancasila sebagai sumber segala sumber hukum”, Mahkamah Konstitusi dapat memiliki dasar yang kuat dalam memberikan putusan atas pembatalan suatu ketentuan dalam undangundang yang bertentangan dengan Pancasila.

Kembali mengenai pentingnya pencantuman "Pancasila" dalam UUD NRI 1945, pencantuman dasar negara atau ideologi suatu negara dalam konstitusi sebenarnya telah dilakukan beberapa negara misalnya Republik Rakyat China. Ideologi sosialisme China diatur dalam Pasal 1 ayat (1) Konstitusi China yang menyatakan bahwa negara China adalah negara sosialis di bawah naungan sistem demokrasi yang dipimpin oleh para kelas pekerja dan aliansi para kelas pekerja dan masyarakat bawah. Selanjutnya dalam ayat 2 lebih jauh ditegaskan bahwa semua usaha yang membahayakan sosialisme China tidak diperbolehkan. ${ }^{27}$ Bunyi ketentuan yang dimaksud sebagai berikut:

27 Beni ahmad Saebani dan Ai Wati, Perbandingan Hukum Tatanegara, (Bandung: Pustaka setia, 2016), 245. 
"Article 1. The People's Republic of China is a socialist state under the people's democratic dictatorship led by the working class and based on the alliance of workers and peasants. The socialist system is the basic system of the People's Republic of China. Sabotage of the socialist system by any organization or individual is prohibited".

Pencantuman ideologi atau dasar negara dalam Konstitusi China sangat berdampak dalam meningkatkan kemajuan negara tirai bambu tersebut. Selama 6o tahun berkuasa sejak tahun 1949, "dinasti" Partai Komunis China telah mengubah wajah negeri itu, antara lain pada bidang ekonomi dengan "sosialisme yang berkarakteristik China". Sebuah perpaduan yang kompleks antara kapitalisme yang kompetitif dan monopoli politik yang kental. Dengan resep sosialisme mereka yang khas itu, China saat ini menjadi negara dengan cadangan devisa luar biasa besar, pertumbuhan ekonomi dua digit, dan eksportir kedua terbesar di dunia. Di sisi lain, reformasi dalam bidang politik tetap terus berjalan. ${ }^{28}$ China merupakan negara yang memilki rakyat dengan nasionalisme dan kepatuhan hukum yang tinggi. Saat ini posisi negara China dalam percaturan dunia

${ }^{28}$ https://nasional.kompas.com/read/2009/10/03/05394937/sosialism e. gaya.china?page=all diakses tanggal 23 Mei 2021. 
internasional sangat diperhitungkan setelah Amerika Serikat.

Demikian pula Arab Saudi sebagai negara Islam yang menjadikan Al-Qur'an dan Al-Hadits sebagai dasar hukum dengan mengatur ideologi negara dalam konstitusinya. Basic Law of Government tak ubahnya sebuah konstitusi. Pasal 1 Bab I menyatakan: "Kerajaan Arab Saudi adalah sebuah Negara Islam berdaulat. Agamanya Islam. Konstitusinya adalah Kitab Allah, Al-Qur'an al-Karim, dan As-Sunnah Nabi Muhammad s.a.w. Bahasa Arab adalah bahasa Kerajaan. Kota Riyadh menjadi ibu kota negara." Ketentuan ini kemudian dipertegas dalam pasal-pasal berikutnya:

1. Pasal 7 Bab II: "Pemerintah Arab Saudi mendasarkan kekuasaannya atas Kitab Allah dan Sunnah Nabi, yang merupakan sumber tertinggi rujukan hukum dari Hukum Dasar Pemerintahan ini dan hukum-hukum yang lain.” Pasal 8 Bab II: "Pemerintahan Arab Saudi berdasarkan keadilan, syura (konsultasi) dan persamaan sesuai Syari'at Islam."

2. Pasal 45: "Al-Qur'an al Karim dan As-Sunnah Nabi Muhammad s.a.w. menjadi sumber fatwa. Undang-Undang akan merinci hirarki administrasi komposisi Majelis Ulama Senior, Administrasi Penelitian, dan Kantor Mufti beserta fungsi-fungsinya." 
3. Pasal 48: "Pengadilan-pengadilan menerapkan Shari'at Islam terhadap perkara-perkara yang dibawa kepadanya sesuai Al-Qur'an al-Karim dan As-Sunnah, dan undang-undang yang didekritkan oleh dekrit pemerintah yang sejalan dengan alQur'an al-Karim dan Sunnah." 29

Berdasarkan ulasan tersebut di atas maka perlunya perubahan atau amandemen UUD 1945 dengan memasukkan ketentuan tentang pencantuman istilah "Pancasila" dan Pancasila sebagai sumber segala sumber hukum negara. Penulis menawarkan materi amandemen UUD 1945 yang dimaksud adalah sebagai berikut:

\begin{tabular}{|c|c|c|}
\hline No. & Bunyi Ketentuan & Konsep Amá \\
\hline 1. & $\begin{array}{c}\text { BAB I } \\
\text { BENTUK DAN } \\
\text { KEDAULATAN }\end{array}$ & $\begin{array}{c}\text { BAB I } \\
\text { BENTUK, DASAR } \\
\text { DAN KEDAULATAN }\end{array}$ \\
\hline & $\begin{array}{l}\text { Pasal } 1 \\
\text { (1) Negara Indonesia } \\
\text { ialah Negara } \\
\text { Kesatuan yang } \\
\text { berbentuk } \\
\text { Republik. } \\
\text { (2) Kedaulatan berada } \\
\text { di tangan rakyat } \\
\text { dan dilaksanakan } \\
\end{array}$ & $\begin{array}{l}\text { Pasal } 1 \\
\text { Negara Indonesia ialah } \\
\text { Negara Kesatuan yang } \\
\text { berbentuk Republik. } \\
\text { Pasal } 1 \mathrm{~A} \\
\text { (1) Negara berdasarkan } \\
\text { Pancasila. } \\
\text { (2) Pancasila }\end{array}$ \\
\hline
\end{tabular}

29 Acep Zoni Saeful Mubarok, Reformasi Konstitusi dan Yudisial dalam Bingkai Konstitusionalisme di Arab Saudi, Journal of Islamic Studies and Humanities Pascasarjana UIN Walisongo Semarang Vol. 2, No. 1 (2017), 7-8 


\begin{tabular}{|c|c|c|}
\hline & $\begin{array}{l}\text { menurut Undang- } \\
\text { Undang Dasar. } \\
\text { (3) Negara Indonesia } \\
\text { adalah negara } \\
\text { hukum. }\end{array}$ & $\begin{array}{l}\text { sebagaimana } \\
\text { dimaksud ayat (1) } \\
\text { tercantum dalam } \\
\text { Pembukaan } \\
\text { Undang-Undang } \\
\text { Dasar yaitu } \\
\text { Ketuhanan Yang } \\
\text { Maha Esa, } \\
\text { Kemanuaiaan yang } \\
\text { adil dan beradab, } \\
\text { Persatuan } \\
\text { Indonesia, } \\
\text { Kerakyatan yang } \\
\text { dipimpin oleh } \\
\text { hikmat/kebijaksana } \\
\text { a dan Keadilan } \\
\text { sosial bagi seluruh } \\
\text { rakyat Indonesia. } \\
\text { (3) Negara Indonesia } \\
\text { adalah negara } \\
\text { hukum. } \\
\text { (4)Pancasila sebagai } \\
\text { sumber dari segala } \\
\text { sumber hukum. } \\
\text { Pedaulatan berada di } \\
\text { tangan rakyat dan } \\
\text { dilaksanakan menurut } \\
\text { Undang-Undang } \\
\text { Dasar. }\end{array}$ \\
\hline 2. & $\begin{array}{l}\text { Pasal } 37 \\
\text { (5) Khusus mengenai } \\
\text { bentuk Negara } \\
\text { Kesatuan } \\
\text { Republik }\end{array}$ & $\begin{array}{l}\text { Pasal } 37 \\
\text { (5) Khusus mengenai } \\
\text { bentuk dan dasar } \\
\text { Negara Kesatuan } \\
\text { Republik }\end{array}$ \\
\hline
\end{tabular}




\begin{tabular}{|l|l|l|}
\hline & $\begin{array}{l}\text { Indonesia tidak } \\
\text { dapat dilakukan } \\
\text { perubahan. }\end{array}$ & $\begin{array}{l}\text { Indonesia tidak } \\
\text { dapat dilakukan } \\
\text { perubahan. }\end{array}$ \\
\hline
\end{tabular}

\section{Kesimpulan}

Konstitusi di Indonesia telah memuat rumusan Pancasila dalam pembukaan atau mukaddimah UndangUndang Dasar, akan tetapi istilah Pancasila dan Pancasila sebagai sumber segala sumber hukum tidak diatur dalam Undang-Undang Dasar. Ketentuan ini berakibat pada timbulnya inkonsistensi peraturan perundang-undangan di bawah Undang-Undang Dasar 1945 yang mencantumkan Pancasila sebagai sumber segala sumber hukum di dalamnya terhadap UndangUndang Dasar 1945. Masih banyaknya peraturan perundang-undangan yang dibatalkan oleh lembaga yang berwenang menunjukkan bahwa pengaturan Pancasila sebagai sumber dari segala sumber hukum baik melalui Tap MPR dan undang-undang tidak mampu memaksa pembuat peraturan perundangundangan menjadikan Pancasila sebagai sumber hukum tertinggi.

Oleh karena itu mengatasi konflik norma tersebut, Majelis Permusyawaratan Rakyat hendaknya melaksanakan amandemen Undang-Undang Dasar 1945 
terutama mengenai pencantuman istilah Pancasila dan pengaturan fungsi Pancasila dalam ketatanegaraan sebagai sumber dari segala sumber hukum. Dengan dipenuhinya amandemen tersebut, maka Pancasila dalam konstitusi di Indonesia telah diatur secara integral baik secara substansial maupun secara formal, sehingga kedudukan Pancasila akan semakin kuat dalam ketatanegaraan Republik Indonesia.

\section{Daftar Pustaka}

Al Marsudi, Subandi. Pancasila dan UUD '45 dalam Paradigma Reformasi. Jakarta: PT RajaGrafindo Persada, 2006.

Asshiddiqie, Jimly dan M. Ali Safa'at, Teori Hans Kelsen tentang Hukum. Jakarta: Setjen dan Kepaniteraan MK-RI, 2006.

Atmadja, Dewa Gede. Hukum Konstitusi Problematika Konstitusi Indonesia Sesudah Perubahan UUD 1945. Malang: Setara Press, 2012.

Jurdi, Fajlurrahman. Hukum Tata Negara Indonesia. Jakarta: Prenadamedia Grup, 2019.

Kaelan. Pendidikan Pancasila. Yogyakarta: Paradigma, 2010. 
Latif, Yudi. Negara Paripurna Historisitas, Rasionalitas, dan Aktualitas Pancasila. Jakarta: Gramedia Pustaka Utama, 2012.

MD, Moh. Mahfud. Dasar \& Struktur Ketatanegaraan Indonesia. Jakarta: Rineka Cipta, 2001.

Saebani, Beni Ahmad dkk. Perbandingan Hukum Tatanegara. Bandung: Pustaka setia, 2016.

Thaib, Dahlan dkk. Teori dan Hukum Konstitusi. Jakarta: PT RajaGrafindo Persada, 2008.

Wahyono, Padmo. Beberapa Masalah Ketatanegaraan di Indonesia. Jakarta: Rajawali, 1994.

Bo'a, Fais Yonas, Pancasila sebagai Sumber Hukum dalam Sistem Hukum Nasional, Jurnal Konstitusi, Volume 15, Nomor 1, Maret 2018.

Mubarok, Acep Zoni Saeful, "Reformasi Konstitusi dan Yudisial dalam Bingkai Konstitusionalisme di Arab Saudi”, Journal of Islamic Studies and Humanities Pascasarjana UIN Walisongo Semarang Volume 2, Nomor 1, 2017.

Santoso, M. Agus. "Perkembangan Konstitusi di Indonesia”, Jurnal Yustisia, Volume2, Nomor 3, September - Desember, 2013.

Cholisin. "Pancasila Sebagai Ideologi Negara dan Relevansinya dengan Kondisi Saat ini”, http://staffnew.uny.ac.id/upload/131474282/peng 
abdian/mgmp-pkn-wates-28-sep-2011-ideologinegara-dan-relevansinya-dengan-kondisi-saatini.pdf, diunduh 26 April 2020.

http://hukum.unsrat.ac.id/pres/konstitusi_ris.pdf, diunduh 28 April 2020.

Masha, Nasihin. "Bermula dari Fragmentasi, Pengaburan Pancasila Yamin dan Desukarnoisasi Orba" REPUBLIKA.co.id Rabu 22 Jun 2016 12:01 WIB, diunduh 6 Mei 2020.

Undang-Undang Dasar 1945.

Undang-Undang Nomor 12 Tahun 2011 tentang Pembentukan Peraturan Perundang-undangan. 